\title{
Specific Instructions for Contributors to the Journal of Public Health Dentistry
}

The Journal of Public Health Dentistry is the official journal of the American Association of Public Health Dentists. Manuscripts are accepted for publication on the condition that they are contributed solely to the Journal. Subsequent publication may be authorized at the discretion of the editor. Generally, manuscripts are scheduled several months in advance. Contributors will be notified when the manuscript has been received and will be advised of the editor's decision. In the covering letter, if the paper has been presented orally before a group, please provide the name of the group, and the date and place of presentation.

Manuscripts are reviewed routinely by at least two referees. Editorial revisions, to add clarity and to conform to Journal style, likely will be made. Authors will be sent page proofs of their papers to proofread for typesetting errors.
Contributors should send to the editor* an original and two copies of the manuscript, and should retain at least one copy of it. For additional details on writing and manuscript preparation, Journal contributors are referred to: Huth EJ. How to write and publish papers in the medical sciences. Philadelphia: ISI Press, c1972:203; and Day, RA. How to write and publish a scientific paper. 2nd ed. Philadelphia: ISI Press, c1983:181.

The Journal's basic reference book for spelling, style, usage, word division, and punctuation is Webster's ninth new collegiate dictionary. Springfield, Mass: Merriam-Webster, 1983:1563. (It is based on Webster's third new international dictionary, unabridged.)

For complete instructions on the Journal's style, please refer to its Fall 1983 issue (Volume 43, Number 4).

*Dr. David F. Striffler

School of Public Health

The University of Michigan

Ann Arbor, MI 48109-2029

313-764-5477 